Historic, archived document

Do not assume content reflects current scientific knowledge, policies, or practices. 



\section{An \\ Opportunity Extraordinary \\ to secure a tree of the \\ Ancient Cypress of the \\ Montezumas}

(Taxodium Mucronatum)

Some of these trees are estimated by scientists to be more than 2000 years old - among the oldest living things on the continent

\section{TEAS NURSERY COMPANY}

Originators and Introducers of

'TEAS' WEEPING MULBERRY

Teas' White Flowering Cercis - Teas' Japan Hybrid Catalpa Etc., Etc. 


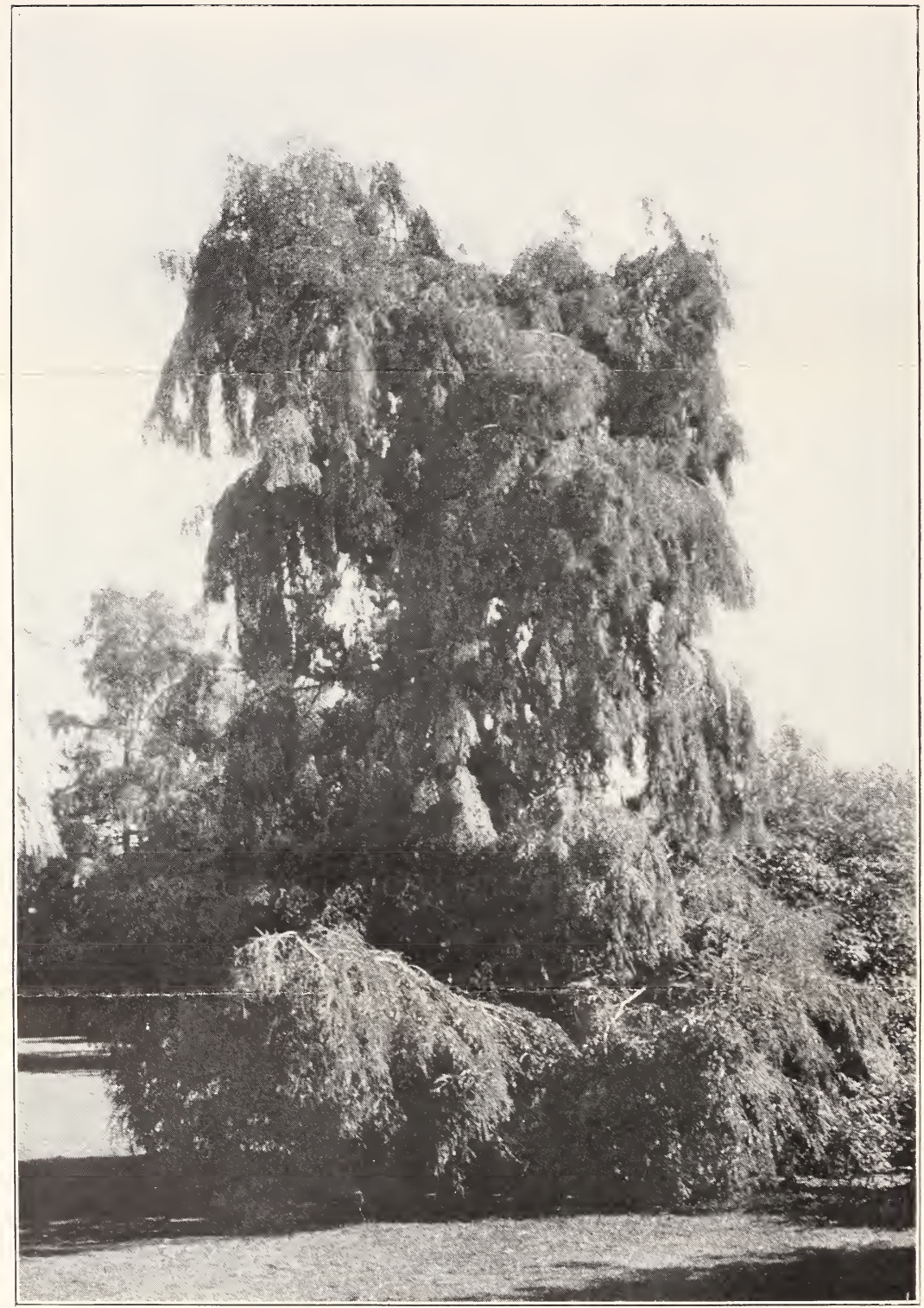

TAXODIUM MUCRONATUM (The Montezuma Cypress) 


\section{Taxodium Mucronatum}

(MONTEZUMA CYPRESS)

7 HIS most beautiful tree from Chapultepec, Mexico, is picturesque in its character, as well as in its historic associations.

Among the most beautiful trees we have ever beheld were brought to our attention on a recent western tour. These trees were growing in a city park in California, and on investigation were found to be Taxodium mucronatum, and direct descendants of the historic Cypress tree of Old Mexico described in the following article, and introduced into California by the late Dr. F. Franceschi, a noted horticulturist and collector at Santa Barbara.

Seed was obtained from these trees, one of which is shown in our illustration-but the most beautiful specimens are growing too close to other trees to permit a photograph to be taken of them.

Our first sowing of seed was not successful, but this year we have grown a quantity of vigorous young trees, and it is our desire to distribute them as widely as possible throughout the southern states, hoping this most beautiful and interesting tree may be introduced into the gardens and home grounds throughout the south.

The foliage, which is evergreen in California, has the same beautiful, soft, feathery, deep green appearance of our native Cypress, but the growth is more dense, and while the trunk of the tree is quite erect, the branches are gracefully pendulous, the lower ones drooping to the ground and swaying in the breeze like downy plumage.

Dr. C. S. Sargent, of the Arnold Arboretum in Boston-America's foremost authority on trees, has kindly sent a description of these majestic monarchs of the forest, copied from Garden and Forest, which we reprint on page four.

Price of vigorous young trees, out of 21/2-inch pots, 1 to 2 feet in height, 50c. each, 6 trees for $\$ 2.00$, by parcel post or express.

Dear Mr. Teas:

Arnold Arboretum, Harvard University

Jamaica Plain, Mass., September 21st, 1923.

I am glad to hear from your letter of the 4 th of September that you have succeeded in raising a lot of seedlings of Taxodium mucronatum, which ought to grow well in several parts of the southern states.

I enclose, as you request, a copy of the article from the third volume of Garden and Forest.

Edward Teas, Esq.,

Yours very truly,

(Signed) C. S. SARGENT.

Teas Nursery Company,

214 Scanlan Building,

Houston, Texas. 


\section{The Cypress of Montezuma}

There appeared not long ago in these columns (volume III, page 2) an account of the deciduous Cypress (Taxodium distichum), with a view of a swamp in southern Indiana covered with a forest of these trees surrounded by their peculiar root growths, the so-called Cypress-knees.

The illustration on page 155 of this issue represents the trunk of a tree of the same species, and one of the most interesting and best known trees in America, the "Cypress of Montezuma," the largest of the famous Cypress trees in the gardens of Chapultepec, near the City of Mexico, and a noted tree nearly four centuries ago. It belongs to the same species as our deciduous Cypress of the southern states, which extends southward through some of the high valleys of Mexico nearly to Guatemala, growing in these southern situatiuns in comparatively dry ground, and without producing the knees which characterize the more northern trees, the inhabitants of deep swamps and inundated river banks. The "Cypress of Montezuma" is a tall and stili graceful tree, rising to a height of 170 feet, with a trunk to which different travelers have ascribed a girth varying from forty to nearly fifty feet, the discrepancies in the measurements being due, no doubt, to the different points above the surface of the ground at which they were made. It stands near the hardly less famous spring, the "Bath of Montezuma," the source of the water supply of the Aztec capital, to which it was carried on a splendid aqueduct of 900 arches.

The tree of Montezuma is only one of a number of individual Cypress trees growing in different parts of Mexico, famous for their antiquity, their vast dimensions, and the historical associations which cluster about them. Distinguished natralists* have examined their history and computed their age, which in the case of the "Cypress of Montezuma," has been estimated to be about seven centuries; while that of the larger tree of Santa Maria del Tule is believed to be nearly 2,000 years old. This tree, the largest deciduous Cypress of which there is any authentic record, stands in the center of the village of Tule, on the road from Oazaca to Guatemala by way of Tehuantepec, within the enclosure of the parish church, and is a conspicuous object from all the country round. The measurements of this tree given by travelers vary a great deal, and it is difficult to compare them satisfactorily, as they generally lack precise information of the exact manner in which they were made. The latest measurements of this tree which we have seen, were made a year ago and are as follows: Circumference of the trunk 5 feet from the ground, following all its sinuosities, 146 feet; actual circumference, 5 feet from the ground, 104 feet; total height of the tree, 150 feet; longest diameter of the trunk, 40 feet; shortest diameter of the trunk, 20 feet; spread of branches, 141 feet.

Hardly less famous than the Cypress of Santa Maria del 'Tule is the Ahuehuete of the village of Atlisca near Puebla, of which the worthy Archibshop wrote three centuries ago, as quoted by Gray: "The cavity of the trunk might contain twelve or thirteen men on horseback; and that in the presence of the most illustrious Archbishop of Guatemala and the Bishop of Puebla more than a hundred boys entered it." This tree, according to Humboldt's measurements, had in his time a trunk girth of sixty-six English feet, the cavity of the trunk being about 16 feet in diameter.

"El Arbor de la Noche triste," the Tree of the Night of Sorrow, another of the great Mexican Taxodiums, stands in the little village of Popatela. It marks the spot where the soldiers of Cortez went down like sheep before the Aztec hordes, their backs to the foe. The trunk of this tree girths about 60 feet, and although the top and many of the branches are in a state of advanced decay, the tree still rises above the little church close to which it stands and which was built to commemorate the battle.

*Humboldt, “Essai Polit. Nov. Esp.,” ed. 2 ii., 54.-A. De Candolle, in Bibl. Univ. de Geneve, xlvi., 392.-A. Gray, "Scientific Papers," ii., 113. 